\title{
Potential utilization of quartz sand and kaolin from tin mine tailings for whiteware
}

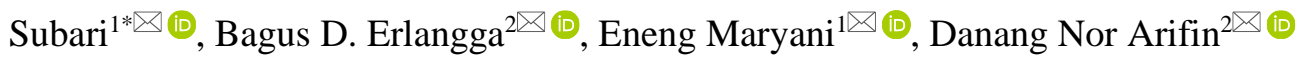 \\ ${ }^{1}$ Center for Ceramics, Ministry of Industry, Bandung, 40272, Indonesia \\ ${ }^{2}$ Research Center for Geotechnology, Indonesian Institute of Sciences, Bandung, 40135, Indonesia \\ *Corresponding author: e-mail subaribbk@gmail.com, tel. +6281222685818
}

\begin{abstract}
Purpose. To do experimental research into the potential utilization of residual quartz-based sands and kaolin from the tin mine tailings in Bangka Belitung Province, Indonesia.

Methods. Process of raw materials beneficiation by washing, vibration on the screen, magnetic separation. Manufacturing whiteware from beneficiated quartz sand, beneficiated kaolin, ball clay and feldspar. The whiteware properties were analyzed in terms of shrinkage, water absorption, flexural strength, and whiteness index.

Findings. The amount of iron oxide in the quartz sand and the kaolin was reduced by beneficiation process from $1.12 \%$ and 1.06 to $0.51 \%$ and $0.5 \%$, respectively. The whiteware specimens showed the required physical and mechanical properties. Thus, these raw materials can principally be utilized for the manufacture of whiteware ceramic items with whiteness index up to 68.3.
\end{abstract}

Originality. Quartz sand and kaolin extracted from tin mine tailings were used after beneficiation of raw materials for whiteware manufacture.

Practical implications. This research can provide practical solution to the problem related to mine tailings rich in quartz and kaolin which can be utilized for manufacturing whiteware.

Keywords: tin mine tailings, quartz sand, kaolin, magnetic separation, whiteware ceramics

\section{Introduction}

The tin mine tailings in Bangka Belitung Province, Indonesia were considered as a waste from mining activities. The tailings, which predominantly contain quartz sand, were abandoned in some areas in the province. Until recently, the tailing material has not been utilized for any industrial activities. In a plain view, these tailings can potentially be used as a raw material for industries such as glass and ceramic industries. However, the tailings cannot be used directly due to its impurities such as gravel, clay, iron minerals and organic matter. Based on standard SNI 15-1026-1989, quartz for porcelain type is limited to $\mathrm{Fe}_{2} \mathrm{O}_{3}<0.4 \%$ and $\mathrm{TiO}_{2}<0.3 \%$. In addition to that, the $\mathrm{SiO}_{2}$ content in the sand tailings is still relatively low, which is around $95 \%$, while quartz sand which is used as a raw material for fine ceramic manufacture should have a minimum $\mathrm{SiO}_{2}$ content of $97 \%$ [1].

The beneficiation process needs to be done to increase the $\mathrm{SiO}_{2}$ and reduce the iron and organic impurities in the sand tailings. Some relevant research had been conducted effectively by washing the sand and by the iron separation process using flotation, high intensity magnetic separation or leaching [2], [3]. Besides, attrition scrubbing can also be used in the processing of tailing materials that predominantly contain low level of quartz sand mixed with clay impurities and when the impurities occur in the form of oxide coatings on sand grain surfaces [4], [5].

In addition to the sand tailings, kaolin was also derived from the tin ore refining process. The kaolin by-product came with some impurities such as gravel, red clay, and organic matter. Beneficiation is also needed to remove or reduce some impurities and improve the quality of kaolin. Kaolin can be called white clay because the colour remained white after being burned at $1250-1300^{\circ} \mathrm{C}$ [6]. Therefore, kaolin is one of the basic ingredients for whiteware application. SNI 15-0578-1996 [7] specifies that kaolin for fine ceramic should have maximum $\mathrm{Fe}_{2} \mathrm{O}_{3}$ in the range of 0.4-1.0\%, depending on its ceramic class. Aigbodion et al. (2010) [8] had been experimenting with tin mine tailings from Nigeria, containing $4.75 \% \mathrm{Fe}_{2} \mathrm{O}_{3}$, for manufacturing refractory materials. The tailings had refractory properties which means they can withstand pressure at high temperature, but the colour of the specimens became deep-brown. In 
this study, the quartz sand and the kaolin derived from tin mine tailings will undergo beneficiation process and be applied as raw material for manufacturing whiteware ceramics.

In the manufacture of whiteware bodies, there are four main raw materials that need to be prepared. Those are quartz sand, kaolin, ball clay and feldspar. Each of those materials has an important role; quartz sand is used as a building block for the body, kaolin and ball clay serve as plastic components or binder which increase green strength, while feldspar as a fluxing agent [9]. The purpose of this research is to carry out beneficiation of tailing materials, predominantly quartz sand and kaolin from the area of Bangka Belitung Province, with the ultimate aim of applying them as raw materials for producing whiteware ceramics.

\section{Materials and methods}

The samples of quartz sand and kaolin were collected from a tailing disposal area of PT. Timah, a tin mining company, in the region of Tempilang, West Bangka District, Bangka Belitung Province, Indonesia. The quartz sand and the kaolin, in the form of loose particles, were sampled with coning and quartering method to obtain the representative sample. The ball clay and feldspar, the additional raw materials for whiteware, derived from the local area product, have iron content of, 0.97 and $1.24 \%$, respectively.

\subsection{Beneficiation of the quartz sand and the kaolin}

The aim of the beneficiation of quartz sand is to reduce the content of unwanted components, such as ferric, aluminum and titanium oxides, which have adverse effect on manufacturing conventional ceramics. Firstly, the sand sample was washed with water to remove some clay impurities. Washing was conducted by stirring the sample manually in the water with sand and water volume ratio $1: 1$, and then screening. After the sample became slurry, it was screened with a vibrating screen apparatus with 60 mesh or $0.25 \mathrm{~mm}$ sieve to remove coarser fraction (grains size $>0.25 \mathrm{~mm}$ ). Furthermore, the mass of quartz sludge (60-mesh sieve undersize) was screened using a 200-mesh sieve, where the material passed through the sieve was considered as clay material. In order to reduce the iron mineral content from the sand, the dried sand sample (200-mesh oversize) was treated by means of dry magnetic separation using a magnetic ferro filter device.

The magnetic ferro filter (MMF) device employed 20000 gauss magnetic field to process the sample in the form of slurry with dried sample and water volume ratio 1:2. The magnetic component in the sample is attracted by strong magnetic force and remains in the MFF. The non-magnetic component sample will circulate through the device (Fig. 1).

The kaolin beneficiation process was the same as the treatment of sand tailings samples, but the kaolin was derived from the 200-mesh undersize. The sand and kaolin sample (before and after beneficiation process) were analyzed by standard chemical analysis of their oxide contents with the standard of chemical analysis to determine the oxide contents (SNI 0449:2010) [10]. The method comprises atomic absorption spectroscopy (AAS) to determine the reduction of iron content, gravimetry for measuring $\mathrm{SiO}_{2}$ content, titration for determining $\mathrm{Al}_{2} \mathrm{O}_{3}$ and spectrophotometry for $\mathrm{TiO}_{2}$ content. Besides, X-ray diffraction (XRD) was carried out to reveal the mineral contents. Ultimately, scanning electron microscopy (SEM) was used to analyze the morphological structure in the quartz sand to identify clay and organic matter. (a)

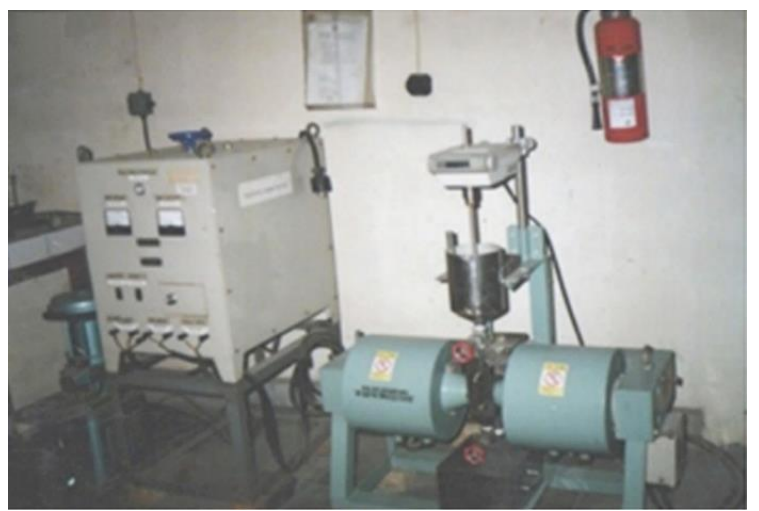

(b)

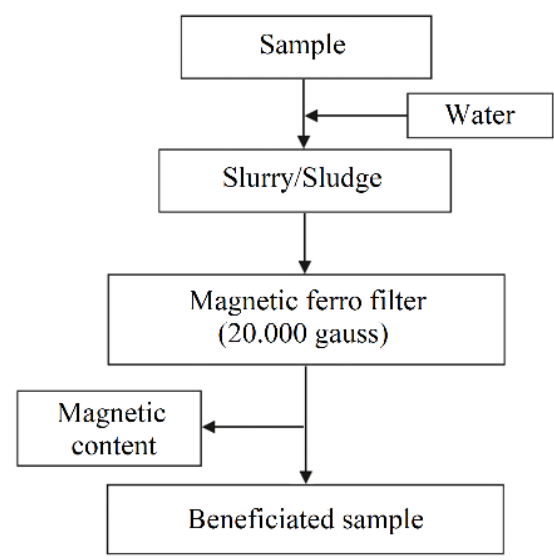

Figure 1. A photograph of magnetic ferro filter device (a) and its flow charts $(b)$

\subsection{Experiment on fabricating whiteware ceramics}

The experiment utilized the beneficiated quartz sand and kaolin with additional feldspar and clay from the local area. The composition of the ceramic body was designed with reference to previous studies, where $50 \%$ clay (consisting of kaolin and ball clay), $25 \%$ feldspar and $25 \%$ quartz sand were used as raw materials [11]. The composition was varied into three different ratios of raw material components shown in Table 1. Quartz sand and feldspar were inversely calculated, while kaolin and ball clay remained in amount as fixed variables.

Table 1. Experimental composition for whiteware

\begin{tabular}{lccc}
\hline Materials & $\begin{array}{c}\text { Composition 1 } \\
\text { wt \% }\end{array}$ & $\begin{array}{c}\text { Composition 2 } \\
\text { wt \% }\end{array}$ & $\begin{array}{c}\text { Composition 3 } \\
\text { wt \% }\end{array}$ \\
\hline $\begin{array}{l}\text { Beneficiated } \\
\text { quartz sand }\end{array}$ & 25 & 20 & 15 \\
\hline $\begin{array}{l}\text { Beneficiated } \\
\text { kaolin }\end{array}$ & 35 & 35 & 35 \\
\hline Ball clay & 20 & 20 & 20 \\
\hline Feldspar & 20 & 25 & 30 \\
\hline
\end{tabular}

The process of fabricating whiteware specimens was began with preparing 2000 grams of materials in accordance with each composition shown in the Table 1. The dry ingredients were mixed and an appropriate amount of water was slowly added to bind them together until the mixture became workable. The mixture was shaped on a plaster mold of $100 \times 15 \times 10 \mathrm{~mm}$ dimension with a solid-casting system. The specimens were dried at $110^{\circ} \mathrm{C}$ for $24 \mathrm{~h}$ to evaporate the moisture. Ultimately, the specimens were heated in an elec- 
tric furnace at $1280^{\circ} \mathrm{C}$ for $9 \mathrm{~h}$. The properties of those specimens were analyzed for shrinkage, water absorption, flexural strength and whiteness value.

The shrinkage value was calculated by dividing the change of the length of the bulk specimen by the initial length $(100 \mathrm{~mm})$ in percentage. The formula for calculating the shrinkage data is as follows:

Shrinkage $=\frac{\text { drylength }- \text { fired length }}{\text { drylength }} \cdot 100 \%$.

The water absorption was determined by soaking the specimen in the water for $24 \mathrm{~h}$. The specimen was weighed before (dried weight) and after the soaking process (soaked weight). The percentage of water absorption is calculated by dividing the difference of the dried weight $(D)$ and the soaked weight $(S)$ by the dried weight $(D)$, as shown in the following formula:

Water absorption $=\frac{S-D}{D} \cdot 100 \%$.

The flexural strength test was performed by three-point loading method (Fig. 2). The specimen was placed symmetrically on the two supporting points (knife edge). Then, the entire load was applied at the center of the specimen. The flexural strength or the modulus of rupture value was calculated by Formula 3.

Flexural strength $=\frac{3 L D}{2 b d^{2}} \cdot 100 \%$,

where:

$L$ - breaking load, kg;

$D$ - distance between supports, $\mathrm{cm}$;

$b-$ breadth/width of the specimen, $\mathrm{cm}$;

$d-$ depth/thickness of the specimen, $\mathrm{cm}$.

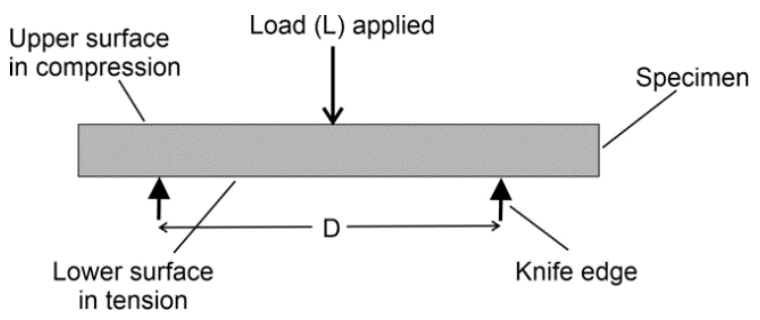

Figure 2. The illustration of three-point loading flexural strength test [9]

\section{Results and discussion}

Based on the data on the chemical composition (Table 2), after being beneficiated the sand from tin mine tailings showed a decrease in the percentage of $\mathrm{Al}_{2} \mathrm{O}_{3}, \mathrm{Fe}_{2} \mathrm{O}_{3}$, and $\mathrm{TiO}_{2}$ and an increase in $\mathrm{SiO}_{2}$ content. The beneficiated sand tailings had $0.51 \%$ iron $\left(\mathrm{Fe}_{2} \mathrm{O}_{3}\right)$ and $0.06 \%$ titanium $\left(\mathrm{TiO}_{2}\right)$ content. Besides, the beneficiated kaolin showed about half reduction in iron content from 1.06 to $0.5 \%$. This low amount of iron and titanium in the quartz sand and kaolin could be beneficial to compensate those contents in the additional materials in manufacturing whiteware. The total amount of $\mathrm{Fe}_{2} \mathrm{O}_{3}$ and $\mathrm{TiO}_{2}$ in the raw materials is preferable to be less than $1 \%$ in the perspective of whiteware application [12].The kaolin with $37.96 \% \mathrm{Al}_{2} \mathrm{O}_{3}$ and $0.5 \% \mathrm{Fe}_{2} \mathrm{O}_{3}$ was supposed to be a potential raw material for whiteware.
Table 2. Oxide contents (in wt. \%) in the sand and the kaolin

\begin{tabular}{ccccc}
\hline $\begin{array}{c}\text { Component } \\
\text { (oxide) }\end{array}$ & $\begin{array}{c}\text { Quartz } \\
\text { sand }\end{array}$ & $\begin{array}{c}\text { Beneficiated } \\
\text { quartz sand }\end{array}$ & Kaolin & $\begin{array}{c}\text { Beneficiated } \\
\text { kaolin }\end{array}$ \\
\hline $\mathrm{SiO}_{2}$ & 95.06 & 98.77 & 53.12 & 48.25 \\
\hline $\mathrm{Al}_{2} \mathrm{O}_{3}$ & 0.43 & 0.39 & 34.78 & 37.96 \\
\hline $\mathrm{Fe}_{2} \mathrm{O}_{3}$ & 1.12 & 0.51 & 1.06 & 0.50 \\
\hline $\mathrm{TiO}_{2}$ & 0.07 & 0.06 & 0.29 & 0.34 \\
\hline
\end{tabular}

The X-ray diffraction (XRD) pattern of quartz sand mostly corresponded to the quartz. There is no indication of iron oxide in the sand tailings before and after the beneficiation process, which is shown in the Figure 3. This is probably because the percentage of the iron oxide is very low, so that the iron peak is hardly visible. The same absent of iron oxide phase also appeared in the XRD graph of the kaolin. The beneficiated kaolin showed a decline in quartz phase followed by the increase of kaolin group of minerals and illite (Fig. 4).

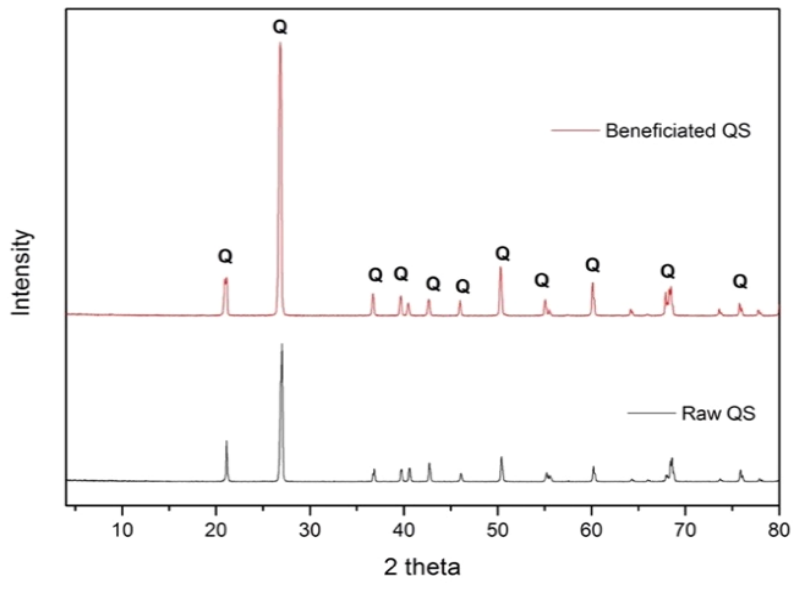

Figure 3. XRD pattern of the quartz, sand (QS): $Q-$-quartz, $\mathrm{SiO}_{2}$

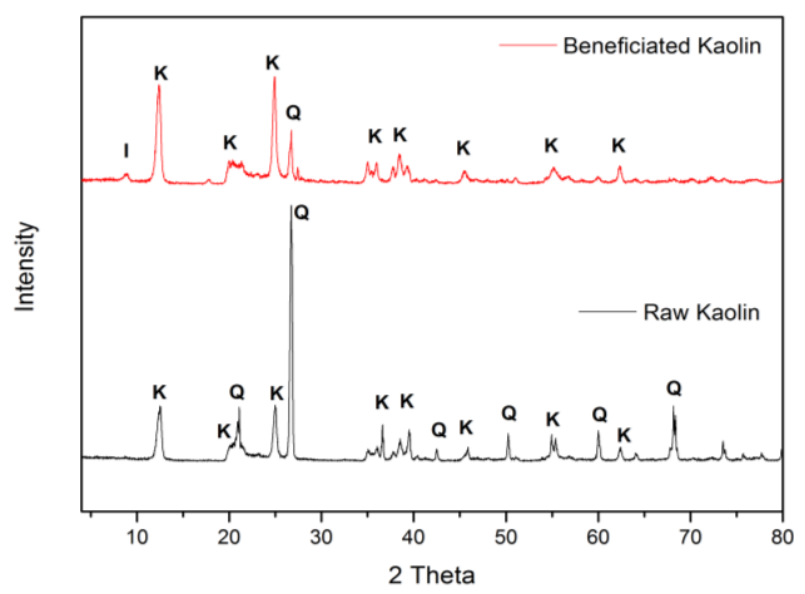

Figure 4. XRD pattern of the kaolin: $Q$-quartz, $\mathrm{SiO}_{2} ; \mathrm{K}-$ kaolin group of minerals; I - illite

This is in line with a previous research by Bertolotti and Kuparadze (2018) [6], which used raw kaolinitic clays containing $\mathrm{Fe}_{2} \mathrm{O}_{3}$ ranging from $0.40-3.62 \%$, resulted in a range of white colour for the clays with $\mathrm{Fe}_{2} \mathrm{O}_{3}$ less than or equal to $1 \%$. The beneficiated quartz sand and kaolin, therefore, were supposed to be potential raw materials for whiteware.

In addition to the XRD analysis, SEM was employed to distinguish the morphology between the sand tailings before and after being beneficiated. The SEM micrographs of those sand surface can be seen in Figure 5 with 10000 magnification. 
(a)

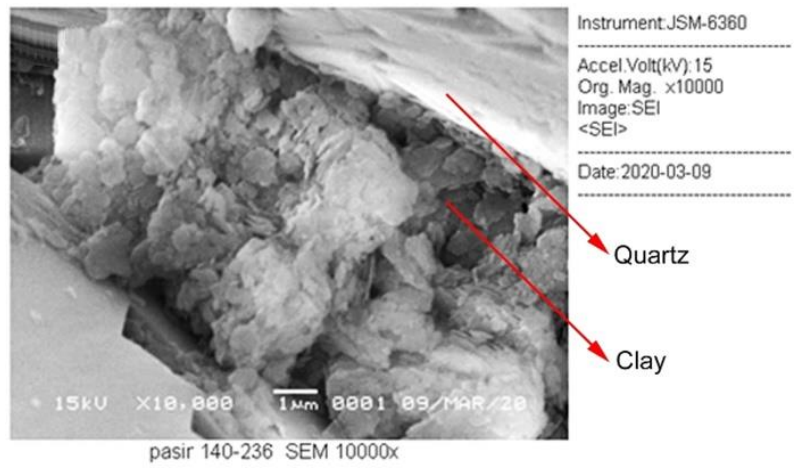

(b)

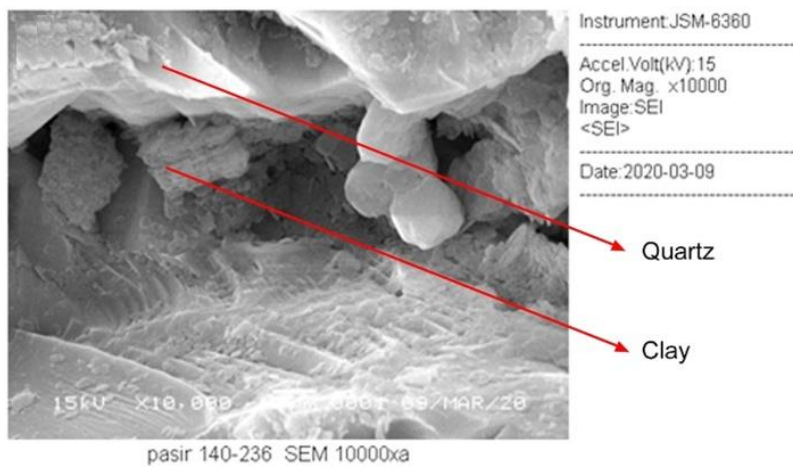

Figure 5. SEM micrographs of sand tailings before (a) and after (b) beneficiation

The morphology of the raw sand tailings showed the quartz mineral with considerable amount of clay and some organic texture. The organic matter was considered to be a part of plants from the surroundings. The beneficiated sand appears to have dominant quartz content followed by lesser clay content compared to the raw sand and no longer contained organic impurities.

\subsection{Whiteware body quality}

Table 4 represents some data related to obtained quality of whiteware body specimens expressed through quality indicators: shrinkage, water absorption, flexural strength and whiteness. According to these data, the water absorption value was below $1.0 \%$, which matches the porcelain body standard i.e. a requirement for manufacturing tableware ceramics [13], [14]. Water absorption values were possibly affected by the amount of feldspar; the more feldspar will result in the lower water absorption value. This is because the feldspar, which also functions as a flux when burned at high temperatures, melts and reacts with other substances, fills the pores in the process and consequently became denser.

Table 4. Characterization of whiteware specimens after being fired at $1280^{\circ} \mathrm{C}$

\begin{tabular}{lccc}
\hline \multicolumn{1}{c}{ Tests } & Composition 1 & Composition 2 & Composition 3 \\
\hline Shrinkage, \% & 9.63 & 9.85 & 10.21 \\
\hline $\begin{array}{l}\text { Water } \\
\text { absorption, \% }\end{array}$ & 0.94 & 0.91 & 0.87 \\
\hline $\begin{array}{l}\text { Flexural } \\
\text { strength, } \\
\text { kg/cm }\end{array}$ & 471.5 & 476.8 & 460.3 \\
\hline Whiteness & 68.3 & 67.2 & 65.4 \\
\hline
\end{tabular}

Quartz sand acts as a filler in the mixture and a reinforcement in the conventional ceramics, so that provides better strength performance. Therefore, it can be seen that the higher amount of quartz sand in the mixture resulted in lower level of shrinkage. However, the use of higher quartz sand followed by insufficiency of feldspar reduced the flexural strength as in composition 1 . This phenomenon can cause by the increasing quartz sand which improve the hardness, rigidity and lower shrinkage [15], but at some level where the quartz is excessive can lead to some detrimental microstructure for its bending strength [16]. In essence, the adequate amount of quartz sand and feldspar was crucial for higher flexural strength, at $476.8 \mathrm{~kg} / \mathrm{cm}^{2}$ as performed in the composition 2. Even though the flexural strength of the three different composition was fluctuating, those all values are still in the range of acceptable flexural strength for whiteware [17], [18]. The kaolin also has an important role especially in maintaining creep resistance in conventional ceramics. This is probably because the kaolin could form some mullite crystals $\left(3 \mathrm{Al}_{2} \mathrm{O}_{3} 2 \mathrm{SiO}_{2}\right)$ at high temperature which support the mechanical strength [19].

In addition, it is apparent that the whiteness value became lower with the higher content of feldspar. This is probably because of influence of iron content in feldspar and the iron content in ball clay, that is rather high i.e., $0.97 \%$ and $1.24 \%$, respectively. The use of higher content of beneficiated quartz sand and lower content of feldspar resulted in greater whiteness of the ceramic body, as shown in Figure 6. Above all, the use of feldspar as a flux with content between $20-30 \%$, quartz as a filler with content between $15-25 \%$ and kaolin with $35 \%$ content in the mixture, resulted in whiteness index ranging from 65.4 to 68.3 . (a)

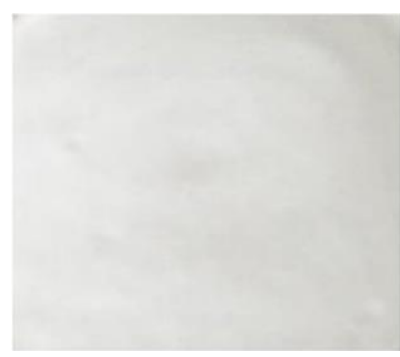

(c)

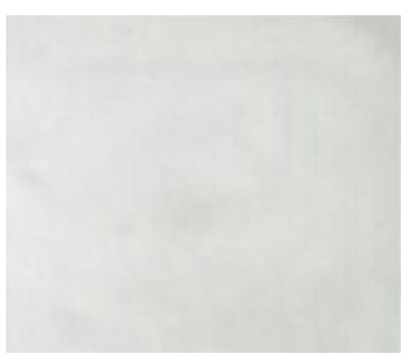

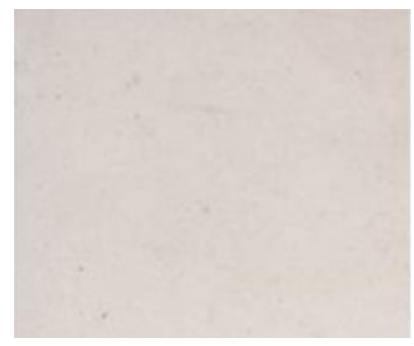

Figure 6. The photograph of whiteware specimens and its whiteness index: (a) whiteness 68.3; (b) whiteness 67.2; (c) whiteness 65.4

\subsection{Whiteware ceramic application}

The highest whiteness value of the ceramic body obtained in conducted tests is 68.3 degree (raw material composition: $25 \%$ beneficiated quartz sand, $35 \%$ beneficiated kaolin, $20 \%$ 
ball clay and $20 \%$ feldspar). The raw material composition was applied to fabricate a tableware ceramic product. The bowl form was achieved using a slip casting in the gypsum mold. The results are perfect in the sense that the prototype does not experience cracks after being casted (Fig. 7).

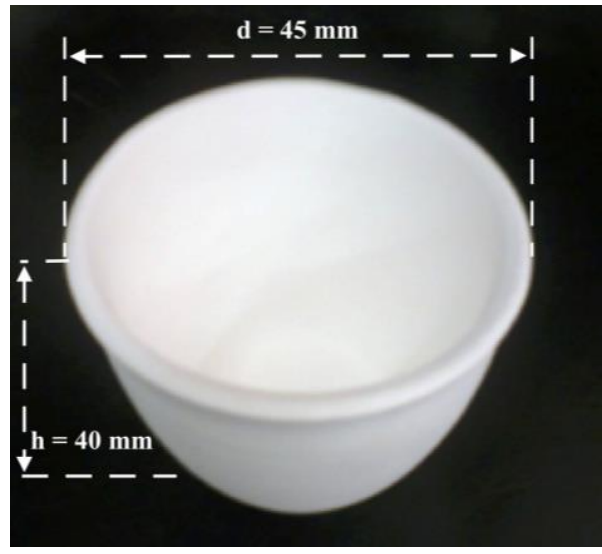

Figure 7. A prototype of whiteware ceramic body

\section{Conclusions}

It can be concluded that a beneficiation process is necessary to improve the quality of tin mine tailings containing the quartz sand and the kaolin, from Bangka Belitung area, so that they can be utilized as raw materials in the manufacture of white ceramic bodies. The pretreatment can be conducted by washing and sieving to remove coarser size and organic matter. The $\mathrm{Fe}_{2} \mathrm{O}_{3}$ content in the raw materials have a marked effect on the whiteness. Using the beneficiation process by means of magnetic ferro filtration, $\mathrm{Fe}_{2} \mathrm{O}_{3}$ content in the quartz sand and kaolin decreased from 1.12 to $0.51 \%$ and from 1.06 to $0.5 \%$, respectively. The quartz sand was purified to $\mathrm{SiO}_{2}$ content of $98.77 \%$. The content of clay minerals in the kaolin, such as kaolin group of minerals and illite, increased, while quartz and iron oxide contents decreased. The whiteware specimens, made of the beneficiated quartz, the beneficiated kaolin, feldspar and clay, showed the required physical and mechanical properties. These raw materials can principally be utilized for the manufacture of whiteware ceramic bodies with whiteness index up to 68.3 .

\section{Acknowledgements}

The authors would like to thank the head of Center for Ceramics, Ministry of Industry and the head of Research Centre for Geotechnology - LIPI and also for those who provide substantial help in this study.

\section{References}

[1] SNI 15-1026-1989. (1989). Quarts for fine ceramic manufacture, porcelain type. Jakarta, Indonesia: National Standardization Body, 9 p.

[2] Chammas, E., Panias, D., Taxiarchou, M., Anastassakis, G.N., \& Paspaliaris, I. (2001). Removal of iron and other major impurities from silica sand for the production of high added value materials. Proceedings of the $9^{\text {th }}$ Balkan Mineral Processing Congress (pp. 289-295). Istanbul, Turkey: Beril Ofset.

[3] Bouabdallah, S., Bounouala, M., \& Chaib, A.S. (2015). Removal of iron from sandstone by magnetic separation and leaching: Case of elaouana deposit (Algeria). Mining Science, (22), 33-44. https://doi.org/10.5277/msc152203

[4] Sobota, I., Salopek, B., Bedeković, G., \& Kutlić, A. (2011). Possibility of beneficiation of silica sand from the croatian de-posits using attrition scrubbing. The Mining-Geology-Petroleum-Engineering Bulletin (Rudarsko-Geološko-Naftni Zbornik), 23(1), 53-66.

[5] Valchev, A., Ignatova, T., Grigorova, I., \& Nishkov, I. (2014). Recovery of feldspar and silica sand from arkosic sandstones. Proceedings of the XXVII International Mineral Processing Congress (pp. 244-256). Santiago, Chile: IMPC Organization.

[6] Bertolotti, G.P., \& Kuparadze, D. (2018). White firing clays from Western Georgia. International Ceramic Review, 67(1-2), 10-19. https://doi.org/10.1007/s42411-018-0001-8

[7] SNI 15-0578-1996. (1996). Kaolin as raw materials for fine ceramic mass. Jakarta, Indonesia: National Standardization Body, 8 p.

[8] Aigbodion, V.S., AbdulRasheed, A., Olajide, S.O., Agunsoye, J.O., \& Sulaiman, I.Y. (2010). Potential of tin tailings an industrial waste for refractory materials. Journal of Minerals and Materials Characterization and Engineering, 9(2), 123-131. https://doi.org/10.4236/jmmce.2010.92011

[9] Ryan, W., \& Radford, C. (1987). Whitewares: Production, testing and quality control the institute of ceramics. New York, United States: Pergamon Press, $333 \mathrm{p}$

[10] SNI 0449-2010. (2010). Clay and feldspar, test method for wet chemical method. Jakarta, Indonesia: National Standardization Body, $17 \mathrm{p}$.

[11] Iqbal, Y. (2008). On the glassy phase in tri-axial porcelain bodies. Journal of Pakistan Materials Society, 2(2), 62-71.

[12] Ghosh, S.N., \& Sen, S. (1961). Effect of iron oxide and titania on the fired colour of clays and whiteware bodies. Transactions of the Indian Ceramic Society, 20(2), 43-53. https://doi.org/10.1080/0371750X.1961.10855418

[13] Firat, F.A., Ercenk, E., \& Yilmaz, S. (2012). Effect of substitution of basalt for quartz in triaxial porcelain. Journal of Ceramic Processing Research, 13(6), 756-761.

[14] Subari, \& Wahyudi, T. (2014). Improving tapin kaolin quality for white ware ceramic. Indonesian Mining Journal, 17(2), 87-97.

[15] Abiola, O.A., Oke, A.O., Omidiji, B.V., \& Adetan, D.A. (2019). The effect of beneficiation on some properties of Osun state ceramic raw materials. Journal of Casting \& Materials Engineering, 3(3), 62-66. https://doi.org/10.7494/jcme.2019.3.3.62

[16] Rajamannan, B., Ramesh, M., Viruthagiri, G., \& Ponnarasi, K. (2011) Mechanical properties of ceramic whiteware samples with different amounts of quartz addition. Elixir Chemical Physics, (33), 2219-2222.

[17] Toluwalope, O., Oluwagbenga, F.B., \& Daniel, L.Y. (2015). Development of whiteware bodies using china clay from select-ed deposits in Edo and Ekiti States of Nigeria. I-Manager's Journal on Material Science, 3(2), 14-20. https://doi.org/10.26634/jms.3.2.3502

[18] Zimmer, A., \& Bragança, S.R. (2019). A review of waste glass as a raw material for whitewares. Journal of Environmental Management, (244), 161-171. https://doi.org/10.1016/j.jenvman.2019.05.038

[19] Akwilapo, L.D., \& Wiik, K. (2004). Ceramic properties of pugu kaolin clays. Part 2: Effect of phase composition on flexural strength. Bulletin of the Chemical Society of Ethiopia, 18(1), 7-16. https://doi.org/10.4314/bcse.v18i1.61631

\section{Можливе використання кварцового піску і каоліну з хвостів олов'яних рудників для виробництва білої кераміки}

\section{Субарі, Б.Д. Ерлангга, Е. Маріані, Д.Н. Аріфін}

Мета. Експериментальні дослідження потенційного використання залишкового кварцового піску та каоліну 3 відходів олов'яних рудників у будівельній індустрії в провінції Бангка Белітунг, Індонезія.

Методика. Кварцовий пісок і каолін у вигляді крихких частинок були відібрані методом конусної і четвертинної обробки для отримання репрезентативної проби. Пісок і каолін попередньо очищені від домішок методами збагачення. Для дослідження хімічного та морфологічного складу використаний стандартний хімічний аналіз для визначення вмісту оксидів SNI 0449:2010. Також використані рентгеноструктурний аналіз і скануюча мікроскопія. Для виготовлення експериментального зразка кераміки використовувався кварцовий пісок, каолін, польовий шпат. Властивості білої кераміки аналізували за усадкою, водопоглинанням, міцністю на вигин та індексом білизни. 
Результати. Встановлено, що процес збагачення необхідний для поліпшення якості хвостів оловяних рудників, що містять кварцовий пісок і каолін при виробництві білої кераміки, який здійснюється шляхом промивання, просіювання та магнітної сепарації для видалення більших частинок і органічних речовин. Визначено, що кількість оксиду заліза у кварцовому піску і каоліні в процесі збагачення зменшилася з 1.12 і 1.06\% до 0.51 і 0.5\% відповідно. Експериментально приготовано та досліджено склад білої кераміки, що складається зі збагаченого кварцового піску, збагаченого каоліну, пластичної глини і польового шпату. Встановлено, що зразки білої кераміки володіють необхідними фізико-механічними властивостями і доведено, що сировина може бути використана для виробництва білих керамічних виробів з індексом білизни до 68.3.

Наукова новизна. Вперше використані кварцовий пісок і каолін з хвостів олов'яних рудників після збагачення сировини для виробництва білої кераміки з характерними фізико-механічними властивостями.

Практична значимість. Це дослідження може надати практичне вирішення проблеми, пов'язаної з хвостами гірничих виробок, багатими кварцом і каоліном, які можуть бути використані для виробництва білої кераміки.

Ключові слова: хвости олов'яних рудників, квариовий пісок, каолін, магнітна сепарація, біла кераміка

\section{Возможное использование кварцевого песка и каолина}

\section{из хвостов оловянных рудников для производства белой керамики}

\section{Субари, Б.Д. Эрлангга, Э. Мариани, Д.Н. Арифин}

Цель. Экспериментальные исследования потенциального использования остаточного кварцевого песка и каолина из отходов оловянных рудников в строительной индустрии в провинции Бангка Белитунг, Индонезия.

Методика. Кварцевый песок и каолин в виде рыхлых частиц были отобраны методом конусной и четвертичной обработки для получения репрезентативной пробы. Песок и каолин предварительно очищены от примесей методами обогащения. Для исследования химического и морфологического состава использован стандартный химический анализа для определения содержания оксидов SNI 0449:2010. Также использованы рентгеноструктурный анализ и сканирующая микроскопия. Для изготовления экспериментального образца керамики использовался кварцевый песок, каолин, полевой шпат. Свойства белой керамики анализировали по усадке, водопоглощению, прочности на изгиб и индексу белизны.

Результаты. Установлено, что процесс обогащения необходим для улучшения качества хвостов оловянных рудников, содержащих кварцевый песок и каолин при производстве белой керамики, который осуществляется путем промывки, просеивания и магнитной сепарации для удаления более крупных частиц и органических веществ. Определено, что количество оксида железа в кварцевом песке и каолине в процессе обогащения уменьшилось с 1.12 и $1.06 \%$ до 0.51 и $0.5 \%$ соответственно. Экспериментально приготовлен и исследован состав белой керамики, состоящий из обогащенного кварцевого песка, обогащенного каолина, пластичной глины и полевого шпата. Установлено, что образцы белой керамики обладают требуемыми физико-механическими свойствами и доказано, что сырье может быть использовано для производства белых керамических изделий с индексом белизны до 68.3 .

Научная новизна. Впервые использованы кварцевый песок и каолин из хвостов оловянных рудников после обогащения сырья для производства белой керамики с характерными физико-механическими свойствами.

Практическая значимость. Это исследование может предоставить практическое решение проблемы, связанной с хвостами горных выработок, богатыми кварцем и каолином, которые могут быть использованы для производства белой керамики.

Ключевые слова: хвосты оловянных рудников, квариевый песок, каолин, магнитная сепарачия, белая керамика 